\title{
PENERAPAN MODEL DISCOVERYLEARNINGMETODE INQUIRYSEBAGAI UPAYA PENINGKATAN PRESTASI BELAJAR EKONOMI DI MA AL-MUJADDADIYYAH MADIUN.
}

\author{
Oleh: \\ Sudjianto \\ Guru Madrasah Aliyah Al-Mujaddadiyyah Kota Madiun
}

\begin{abstract}
:
The teacher as the main implementer of learning to understand and master the application of learning models , make changes and to develop teaching skills . Teachers need to pay attention to the model of learning, because learning model is key to ensuring the learning process in the classroom .

There are three models of learning are applied to the curriculum in 2013 , namely the Discovery Learning model of learning, problem-based learning model and project -based learning model . The learning model discovery learning stimulation / arousal, statement / problem identification, data collection, data processing , verification / evidence and draw conclusions / generalizations . By applying the method of Discovery Learning, students actively seek and cultivate their own information content of higher mental processes or more banyak.siswa will be active in the learning process because one of the friends group is more aware of the material can explain the material to friends who are not informed about .

This research is Classroom Action Research Discovery Learning models by applying the inquiry method. The subjects in this study were students of class XI MA Al - Mujaddadiyyah Madison school year 2013/2014 . The data was collected using the observation sheet to assess learning ability and questionnaire to the data sheet student interest . Analysis of data for learning and student interest using descriptive qualitative analysis, quantitative data by calculating the percentage of first cycle and second cycle .

The results showed that the use of methods can improve the ability of Discovery Learning Study abroad and student interest . Improved learning ability of students can be seen from the increasing number of students who are active in the second cycle, Increasing student achievement can be seen from the increasing student mastery learning and getting better value from each of the aspects which include : discussion of the results of expression, receiving the opinion of the right reasons, concerned about the group, tasks and helping friends .
\end{abstract}

Keywords : Model Discovery Learning, the inquiry method, Learning Achievement .

\section{Pendahuluan}

Kurikulum 2013 sudah mulai diterapkan pada sekolah maupun madarasah.Setiap perubahan kurikulum tentu membawa karakteristik tersendiri.Demikian juga pada model pembelajaran yang diterapkan pada kurikulum baru tersebut. Guru mengenal beberapa model pembelajaran yang telah terbiasa mereka terapkan pada proses pembelajaran. Namun pada kurikulum baru ini, model pembelajaran yang diterapkan berbeda dengan model pembelajaran pada kurikulum sebelumnya. Guru sebagai pelaksana utama pembelajaran harus memahami dan menguasai penerapan model pembelajaran, melakukan 
perubahan dan melakukan pengembangan keterampilan mengajar. Guru perlu memperhatikan model pembelajaran karena model pembelajaran merupakan kunci terlaksananya proses pembelajaran di kelas.

Metode pembelajaran discovery (penemuan) adalah metode mengajar yang mengatur pengajaran sedemikian rupa sehingga anak memperoleh pengetahuan yang sebelumnya belum diketahuinya itu tidak melalui pemberitahuan, sebagian atau seluruhnya ditemukan sendiri. Dalam pembelajaran discovery (penemuan) kegiatan atau pembelajaran yang dirancang sedemikian rupa sehingga siswa dapat menemukan konsep-konsep dan prinsip-prinsip melalui proses mentalnya sendiri. Dalam menemukan konsep, siswa melakukan pengamatan, menggolongkan, membuat dugaan, menjelaskan, menarik kesimpulan dan sebagainya untuk menemukan beberapa konsep atau prinsip.

Metode discovery diartikan sebagai prosedur mengajar yang mementingkan pengajaran perseorang, memanipulasi objek sebelum sampai pada generalisasi. Sedangkan Bruner menyatakan bahwa anak harus berperan aktif didalam belajar. Lebih lanjut dinyatakan, aktivitas itu perlu dilaksanakan melalui suatu cara yang disebut discovery.Discovery yang dilaksanakan siswa dalam proses belajarnya, diarahkan untuk menemukan suatu konsep atau prinsip.

Discovery ialah proses mental dimana siswa mampu mengasimilasikan suatu konsep atau prinsip. Proses mental yang dimaksud antara lain: mengamati, mencerna, mengerti, menggolong-golongkan, membuat dugaan, menjelaskan, mengukur, membuat kesimpulan dan sebagainya. Dengan teknik ini siswa dibiarkan menemukan sendiri atau mengalami proses mental sendiri, guru hanya membimbing dan memberikan intruksi. Dengan demikian pembelajaran discovery ialah suatu pembelajaran yang melibatkan siswa dalam proses kegiatan mental melalui tukar pendapat, dengan berdiskusi, membaca sendiri dan mencoba sendiri, agar anak dapat belajar sendiri.

Tiga ciri utama belajar menemukan yaitu: (1) mengeksplorasi dan memecahkan masalah untuk menciptakan, menggabungkan dan menggeneralisasi pengetahuan; (2) berpusat pada siswa; (3) kegiatan untuk menggabungkan pengetahuan baru dan pengetahuan yang sudah ada.

\section{Model Pembelajaran Discovery Learning}

Metode Discovery Learning adalah cara penyajian pelajaran yang banyak melibatkan siswa dalam proses-proses mental dalam rangka penemuannya.Menurut Sund (Sudirman N, 1992 ), discovery adalah proses mental, dan dalam proses itu individu mengasimilasi konsep dan prinsip-prinsip.Istilah asing yang sering digunakan untuk metode ini ialah discovery yang berarti penemuan, atau inquiryyang berarti mencari. Mengenai penggunaan istilah discovery dan inquiry para ahli terbagi ke dalam dua pendapat, yaitu :

- Istilah-istilah discovery dan inquiry dapat diartikan dengan maksud yang sama dan digunakan saling bergantian atau keduanya sekaligus.

- Istilah discovery, sekalipun secara umum menunjuk kepada pengertian yang sama dengan inquiry, pada hakikatnya mengandung perbedaan dengan inquiry.

Moh. Amin (Sudirman N, 1992 ) menjelaskan bahwa pengajaran discoveryharus meliputi pengalaman-pengalaman belajar untuk menjamin siswa dapat mengembangkan proses-proses discovery. Inquiry dibentuk dan meliputi discovery dan lebih banyak lagi. Dengan kata lain, inquiry adalah suatu perluasan proses-proses discovery yang digunakan dalam cara lebih dewasa. Sebagai tambahan pada prosesproses discovery, inquiry mengandung proses-proses mental yang lebih tinggi tingkatannya, misalnya merumuskan problema sendiri, merancang eksperimen, 
melakukan eksperimen, mengumpulkan dan menganalisis data, menarik kesimpulan, mempunyai sikap-sikap obyektif, jujur, hasrat ingin tahu, terbuka, dan sebagainya.

\section{Jenis-Jenis Model Pembelajaran Discovery Learning}

Moh. Amin (Sudirman N, 1992) menguraikan tentang jenisdiscoverylearningyang dapat diikuti sebagai berikut :

\section{a. Guided Discovery-Inquiry Lab. Lesson}

Sebagian perencanaan dibuat oleh guru.Guru menyediakan bimbingan atau petunjuk yang luas kepada siswa. Siswa tidak merumuskan problema, sementara petunjuk yang cukup luas tentang bagaimana menyusun dan mencatat diberikan oleh guru.

\section{b. Modified Discovery-Inquiry}

Guru hanya memberikan problema saja. Kemudian siswa diundang untuk memecahkannya melalui pengamatan, eksplorasi dan atau melalui prosedur penelitian untuk memperoleh jawabannya. Pemecahan masalah dilakukan atas inisiatif dan caranya sendiri secara berkelompok atau perseorangan..

\section{c. Free Inquiry}

Kegiatan free inquiry dilakukan setelah siswa mempelajarai dan mengerti bagaimana memecahkan suatu problema dan telah memperoleh pengetahuan cukup tentang bidang studi tertentu serta telah melakukan modified discovery-inquiry.

\section{d. Invitation Into Inquiry}

Siswa dilibatkan dalam proses pemecahan problema sebagaimana cara-cara yang lazim diikuti scientist. Memberikan problema kepada siswa melalui pertanyaan masalah yang telah direncanakan, mengundang siswa untuk melakukan kegiatan sebagai berikut : merancang eksperimen, merumuskan hipotesis, menetapkan kontrol, menentukan sebab akibat, menginterpretasi datadan membuat grafik

\section{e. Inquiry Role Approach}

Merupakan kegiatan proses belajar yang melibatkan siswa dalam tim-tim yang masing-masing terdiri atas empat anggota untuk memecahkan invitation into inquiry. Masing-masing anggota tim diberi tugas suatu peranan yang berbeda-beda sebagai berikut : koodinator tim, penasihat teknis, pencatat data dan evaluator proses

\section{Metode Pembelajaran Inquiry}

Salah satu metode pembelajaran sampai sekarang masih tetap dianggap sebagai metode yang cukup efektif adalah metode inquiry. David L. Haury dalam artikelnya, Teaching Science Through Inquiry (1993) mengutip definisi yang diberikan oleh Alfred Novak: inquiry merupakan tingkah laku yang terlibat dalam usaha manusia untuk menjelaskan secara rasional fenomena-fenomena yang memancing rasa ingin tahu.

Metode inquiry yang mensyaratkan keterlibatan aktif siswa terbukti dapat meningkatkan prestasi belajar dan sikap anak (Haury, 1993). Dalam makalahnya Haury menyatakan bahwa metode inquiry membantu perkembangan antara lain scientific literacy dan pemahaman proses-proses ilmiah, pengetahuan vocabulary dan pemahaman konsep, berpikir kritis, dan bersikap positif.

Metode inquiry merupakan metode pembelajaran yang berupaya menanamkan dasar-dasar berfikir ilmiah pada diri siswa, sehingga dalam proses pembelajaran ini siswa lebih banyak belajar sendiri, mengembangkan kreativitas dalam memecahkan masalah. Siswa benar-benar ditempatkan sebagai subjek yang belajar.Peranan guru dalam pembelajaran dengan metode inquiry adalah sebagai pembimbing dan fasilitator.

Walaupun dalam praktiknya aplikasi metode pembelajaran inquiry sangat beragam, tergantung pada situasi dan kondisi sekolah, namun dapat disebutkan bahwa 
pembelajaran dengan metode inquiry memiliki 5 komponen yang umum yaitu Question, Student Engangement, Cooperative Interaction, Performance Evaluation, dan Variety of Resources (Garton, 2005).

Question.Pembelajaran biasanya dimulai dengan sebuah pertanyaan pembuka yang memancing rasa ingin tahu siswa dan atau kekaguman siswa akan suatu fenomena. Selanjutnya, guru menyampaikan pertanyaan inti atau masalah inti yang harus dipecahkan oleh siswa. Untuk menjawab pertanyaan ini - sesuai dengan Taxonomy Bloom - siswa dituntut untuk melakukan beberapa langkah seperti evaluasi, sintesis, dan analisis

Student Engangement.Dalam metode inquiry, keterlibatan aktif siswa merupakan suatu keharusan sedangkan peran guru adalah sebagai fasilitator. Siswa bukan secara pasif menuliskan jawaban pertanyaan pada kolom isian atau menjawab soal-soal pada akhir bab sebuah buku, melainkan dituntut terlibat dalam menciptakan sebuah produk yang menunjukkan pemahaman siswa terhadap konsep yang dipelajari atau dalam melakukan sebuah investigasi.

Cooperative Interaction. Siswa diminta untuk berkomunikasi, bekerja berpasangan atau dalam kelompok, dan mendiskusikan berbagai gagasan.Dalam hal ini, siswa bukan sedang berkompetisi.Jawaban dari permasalahan yang diajukan guru dapat muncul dalam berbagai bentuk, dan mungkin saja semua jawaban benar.

Performance Evaluation. Dalam menjawab permasalahan, biasanya siswa diminta untuk membuat sebuah produk yang dapat menggambarkan pengetahuannya mengenai permasalahan yang sedang dipecahkan.

Variety of Resources. Siswa dapat menggunakan bermacam-macam sumber belajar, misalnya buku teks, website, televisi, video, poster, wawancara dengan ahli, dan lain sebagainya.

\section{Langkah-langkah pembelajaran dalam inkuiri}

Langkah pembelajaran inkuri, merupakan suatu siklus yang dimulai dari:

a. Observasi atau pengamatan terhadap berbagai fenomena alam

b. Mengajukan pertanyaan tentang fenomena yang dihadapi

c. Mengajukan dugaan atau kemungkinan jawaban

d. Mengumpulkan data yang terkait dengan pertanyaan yang diajukan

e. Merumuskan kesimpulan-kesimpulan berdasarkan data.

\section{Aplikasi Pembelajaran Discovery Learning di Kelas}

a. Tahap Persiapan dalam Aplikasi Model Discovery Learning

Seorang guru bidang studi, dalam mengaplikasikan metode discovery learning di kelas harus melakukan beberapa persiapan. Berikut ini tahap perencanaan menurut Bruner, yaitu:

1) Menentukan tujuan pembelajaran.

2) Melakukan identifikasi karakteristik siswa (kemampuan awal, minat, gaya belajar, dan sebagainya).

3) Memilih materi pelajaran.

4) Menentukan topik-topik yang harus dipelajari siswa secara induktif (dari contohcontoh generalisasi).

5) Mengembangkan bahan-bahan belajar yang berupa contoh-contoh, ilustrasi, tugas dan sebagainya untuk dipelajari siswa. 
6) Mengatur topik-topik pelajaran dari yang sederhana ke kompleks, dari yang konkrit ke abstrak, atau dari tahap enaktif, ikonik sampai ke simbolik.

7) Melakukan penilaian proses dan hasil belajar siswa (Suciati \& Prasetya Irawan dalam Budiningsih, 2005:50).

b. Prosedur aplikasi discovery learning

Adapun menurut Syah (2004:244) dalam mengaplikasikan model Discovery Learning di kelas tahapan yang harus dilaksanakan adalah sebagai berikut:

1) Stimulation (stimulasi/pemberian rangsangan).

Pertama-tama pada tahap ini pelajar dihadapkan pada sesuatu yang menimbulkan kebingungannya, kemudian dilanjutkan untuk tidak memberi generalisasi, agar timbul keinginan untuk menyelidiki sendiri (Taba dalam Affan, 1990:198).

2) Problem statement (pernyataan/ identifikasi masalah).

Guru memberi kesempatan kepada siswa untuk mengidentifikasi sebanyak mungkin masalah yang relevan dengan bahan pelajaran, kemudian salah satunya dipilih dan dirumuskan dalam bentuk hipotesis (jawaban sementara atas pertanyaan masalah) (Syah 2004:244).

3) Data collection (pengumpulan data).

Ketika eksplorasi berlangsung guru juga memberi kesempatan kepada para siswa untuk mengumpulkan informasi sebanyak-banyaknya yang relevan untuk membuktikan benar atau tidaknya hipotesis (Syah, 2004:244).

4) Data processing (pengolahan data).

Menurut Syah (2004:244) data processing merupakan kegiatan mengolah data dan informasi yang telah diperoleh para siswa baik melalui wawancara, observasi, dan sebagainya, lalu ditafsirkan.Data processing disebut juga dengan pengkodean coding/ kategorisasi yang berfungsi sebagai pembentukan konsep dan generalisasi.

5) Verification (pentahkikan/pembuktian).

Verification menurut Bruner, bertujuan agar proses belajar akan berjalan dengan baik dan kreatif jika guru memberikan kesempatan kepada siswa untuk menemukan suatu konsep, teori, aturan atau pemahaman melalui contoh-contoh yang ia jumpai dalam kehidupannya (Budiningsih, 2005:41).

6) Generalization (menarik kesimpulan/generalisasi)

Tahap generalitation/ menarik kesimpulan adalah proses menarik sebuah kesimpulan yang dapat dijadikan prinsip umum dan berlaku untuk semua kejadian atau masalah yang sama, dengan memperhatikan hasil verifikasi (Syah, 2004:244). Atau tahap dimana berdasarkan hasil verifikasi tadi, anak didik belajar menarik kesimpulan atau generalisasi tertentu (Djamarah, 2002:22).

\section{METODOLOGI PENELITIAN}

Menurut Sukidin dkk. (2002:54) ada 4 macam bentuk penelitian tindakan, yaitu: (1) penelitian tindakan guru sebagai peneliti, (2) penelitian tindakan kolaboratif, (3) penelitian tindakan simultan terintegratif, dan (4) penelitian tindakan sosial eksperimental.

Penelitian ini mengacu pada perbaikan pembelajaran yang berkesinambungan.Kemmis dan Taggart (1988:14) (dalam Arikunto, 2002: 83), menyatakan bahwa model penelitian tindakan adalah berbentuk spiral.Tahapan penelitian tindakan pada suatu siklus meliputi perencanaan atau pelaksanaan observasi dan refleksi. Siklus ini berlanjut dan akan dihentikan jika sesuai dengan kebutuhan dan dirasa sudah cukup. 


\section{Rancangan Penelitian}

Sesuai dengan jenis penelitian yang dipilih, yaitu penelitian tindakan, maka penelitian ini menggunakan model penelitian tindakan dari Kemmis dan Taggart (dalam Arikunto, 2002: 83), yaitu berbentuk spiral dari siklus yang satu ke siklus yang berikutnya.Setiap siklus meliputi planning (rencana), action (tindakan), observation (pengamatan), dan reflection (refleksi).

Observasi dibagi dalam setiap siklus, yaitu siklus 1, 2, dan seterusnya, dimana masing siklus dikenai perlakuan yang sama (alur kegiatan yang sama) dan membahas satu sub pokok bahasan yang diakhiri dengan tes formatif di akhir masing putaran. Siklus ini berkelanjutan dan akan dihentikan jika sesuai dengan kebutuhan dan dirasa sudah cukup.

Penelitian ini bertempat di Madrasah Aliyah Al-Mujaddadiyyah Kota Madiun, yang dilaksanakan pada bulan Oktober semester Ganjil 2013/2014. Dengan subyek penelitian adalah siswa-siswi Kelas XI dengan pokok bahasan Pembangunan Ekonomi .

\section{Prosedur Penelitian}

Penelitian ini dilakukan melalui tiga tahap, yaitu: (1) tahap persiapan, (2) tahap pelaksanaan, dan (3) tahap penyelesaian.

1. TahapPersiapan

Kegiatan yang dilakukan dalam tahap persiapan ini adalah mempersiapkan segala sesuatu yang berhubungan dengan pelaksanaan penelitian. Dalam kegiatan ini diharapkan pelaksanaan penelitian akan berjalan lancer dan mencapai tujuan yang diinginkan. Kegiatan persiapan ini meliputi: (1) kajian pustaka, (2) pengurusan administrasi perijinan, (3) penyusunan rancangan penelitian, (4) orientasi lapangan, dan (5) penyusunan instrumen penelitian.

2. Tahap Pelaksanaan

Pada tahap pelaksanaan penelitian ini, kegiatan yang dilakukan meliputi: (1) pengumpulan data melalui tes dan pengamatan yang dilakukan persiklus, (2) diskusi dengan pengamat untuk memecahkan kekurangan dan kelemahan selama proses belajar mengajar persiklus, (3) menganalisi data hasil penelitian persiklus, (4) menafsirkan hasil analisis data, dan (5) bersama-sama dengan pengamat menentukan langkah perbaikan untuk siklus berikutnya.

3. Tahap Penyelesaian.

Dalam tahap penyelesaian, kegiatan yang dilakukan meliputi: (1) menyusun draf laporan penelitian, (2) menyusun laporan penelitian, (3) merevisi draf laporan penelitian, (4) menyusun naskah laporan penelitian, dan (5) menggandakan laporan penelitian.

\section{Instrumen Penelitian}

Alat pengumpul data dalam penelitian ini adalah tes buatan guru yang fungsinya adalah: (1) Untuk menentukan seberapa baik siswa telah menguasai bahan pelajaran yang diberikan dalam waktu tertentu; (2) Untuk menentukan apakah suatau tujuan telah tercapai; dan (3) Untuk memperoleh suatu nilai (Arikunto, Suharsimi, 2002:149). Sedangkan tujuan dari tes adalah untuk mengetahui ketuntasan belajar siswa secara individual maupun secara klasikal.

Disamping itu untuk mengetahui letak kesalahan-kesalahan yang dilakukan siswa sehingga dapat dilihat dimana kelemahannya, khususnya pada bagian mana TPK yang belum tercapai. Untuk memperkuat data yang dikumpulkan maka juga digunakan metode observasi (pengamatan) yang dilakukan sendiri oleh guru untuk mengetahui dan merekam aktivitas siswa dalam proses belajar mengajar. 


\section{Analisis Data}

Dalam rangka menyusun dan mengolah data yang terkumpul sehingga dapat mengahasilkan suatu kesimpulan yang dapat dipertanggungjawabkan, maka digunakan analisis data kuantitatif dan pada metode observasi digunakan data kualitatif. Cara perhitungan untuk mengetahui ketuntasan belajar siswa dalam proses belajar mengajar sebagai berikut:

1. Merekapitulasi hasil tes.

2. Merekapitulasi hasil pengamatan.

3. Menghitung jumlah skor yang tercapai dengan menggunakan rumus ketuntasan belajar yaitu siswa dikatakan tuntas secara individual jika mendapatkan nilai minimal 75, sedangkan secara klasikal dikatakan tuntas belajar jika jumlah siswa yang tuntas secara individu mencapai $85 \%$ yang telah mencapai daya serap lebih dari sama dengan $75 \%$.

\section{HASIL PENELITIAN DAN PEMBAHASAN Analisis Data Penelitian Persiklus \\ Siklus I}

\section{Tahap Perencanaan}

Perencanaan tindakan kelas meliputi penyusunan rencana pembelajaran dengan menggunakan strategi inquiri atau pemecahan masalah.Sebagai pendamping guru menggunakan buku paket yang dimiliki oleh setiap siswa, yang menekankan pada aktivitas mengamati, menganalisis, menyimpulkan dan mengkomunikasikan kepada teman.Dalam kaitannya dengan hal itu guru membuat lembar observasi dan alat evaluasi untuk mengetahui keberhasilan belajar siswa.

\section{Tahap Kegiatan dan Pelaksanaan}

a) Ditinjau dari aktivitas siswa

Dari Minat dan keaktifan siswa diketahui bahwa (a) minat dan perhatian siswa dalam proses pembelajaran sebanyak 16 siswa atau 56,77\%, (b) Keaktifan siswa dalam bertanya sebanyak 19 siswa atau 76,31\%, (c) Keaktifan siswa dalam menjawab sebanyak 17 siswa atau 71,02\%, (d) Keaktifan siswa dalam mengeluarkan pendapat sebanyak 18 siswa atau $68,4 \%$

a) Ditinjau dari Perhatian Siswa

Perhatian siswa dalam kegiatan pembelajaran: (1) Perhatian terhadap materi yang disampaikan diperoleh hasil 23 siswa yang aktif atau 86,84\%; (2) Perhatian terhadap tugas yang diberikan diperoleh hasil 23 siswa yang aktif atau 78,94\%; (3) Perhatian terhadap Keaktifan dalam diskusi diperoleh hasil 25 siswa yang aktif atau 84,27\%; (4) Perhatian terhadap Keberanian dalam membacakan hasil diskusidiperoleh hasil 24 siswa yang aktif atau 81,57\%; (5) Perhatian untuk menuliskan ringkasan materi diperoleh hasil 23 siswa yang aktif atau 78,94\%.

b) Ditinjau dari ketuntasan belajar

Dengan menerapkan model Discovery Learningdalam pengajaram cooperative learningdiperoleh nilai rata-rata prestasi belajar siswa adalah 75,93 dan ketuntasan belajar mencapai $51 \%$ atau ada 16 siswa dari 30 siswa sudah tuntas belajar. Hasil tersebut menunjukkan bahwa pada siklus pertama secara klasikal siswa belum tuntas belajar, karena siswa yang memperoleh nilai $\geq 75$ hanya sebesar $51 \%$ lebih kecil dari persentase ketuntasan yang dikehendaki yaitu sebesar $85 \%$. 


\section{Refeleksi}

Dalam pembelajaran dengan metode strategi inquiri diperoleh catatan dalam observasi atau pengamatan pada siklus ke I sebagai berikut :

1) Jumlah kelompok sebanyak 6 kelompok dan dalam setiap kelompok terdiri dari 5 orang, dianggap sudah efektif dan efisien, walaupun tidak semua siswa dapat terlibat dalam kegiatan diskusi.

2) Materi yang ada belum sepenuhnya dapat dibahas oleh kelompok, terutama terhadap indicator atau materi yang dianggap sulit.

3) Siswa belum mempunyai pengalaman terhadap penggunaan strategi inquiri, dan bahkan ada sebagian anak yang tidak serius dalam pembelajaran, oleh sebab itu harus diperbaiki.

4)Ada sebagian siswa yang belum menggunakan kelompok sebagai wahana pembelajaran, sehingga mereka masih berupaya mendominasi dalam pembicaraan.

5) Pembagian waktu belum sepenuhnya sesuai rencana yang telah ditetapkan.

\section{Revisi Pelaksanaan}

Dalam pembelajaran dengan metode strategi inquiri diperoleh catatan dalam observasi atau pengamatan pada siklus ke I sebagai berikut :

1) Jumlah kelompok sebanyak 6 kelompok dan dalam setiap kelompok terdiri dari 5 orang, dianggap sudah efektif dan efisien, walaupun tidak semua siswa dapat terlibat dalam kegiatan diskusi.

2) Materi yang ada belum sepenuhnya dapat dibahas oleh kelompok, terutama terhadap indicator atau materi yang dianggap sulit.

3) Siswa belum mempunyai pengalaman terhadap penggunaan strategi inquiri, dan bahkan ada sebagian anak yang tidak serius dalam pembelajaran,

4)Ada sebagian siswa yang belum menggunakan kelompok sebagai wahana pembelajaran, sehingga mereka masih berupaya mendominasi dalam pembicaraan.

5) Pembagian waktu belum sepenuhnya sesuai rencana yang telah ditetapkan.

Upaya perbaikan dari kendala yang ditimbulkan pada siklus I antara lain :

1) Guru ikut mendampingi kelompok yang presentasi untukmenambahi penjelasan dari siswa.

2) Guru memberi bimbingan dan motivasi kepada kelompok yangkurang aktif dalam menanggapi dan menjawab pertanyaan.

3) Memberi kesempatan siswa untuk belajar dan bertanya lagi padaguru tentang materi yang dirasa kurang jelas.

4) Menambah waktu agar materi dapat dikaji semua pada siklus II .

\section{Siklus II}

\section{Perencanaan}

Perencanaan merupakan tahap awal setelah adanya refleksi pada siklus ke I. Dalam tahap perencanaan ini diharapkan dapat (1) memperbaiki adanya pembelajaran dengan pendekatan inquiri; (2) mengefektifkan kelompok dalam pembelajaran; (3) memotivasi dan memonitor perubahan yang terjadi setelah menggunakan inquiri; (4) melakukan evaluasi terhadap keberhasilan belajar siswa setelah digunakan pembelanjaran strategi inquiri siklus ke II.

\section{Pelaksanaan}


Pelaksanaan tindakan ini dilakukan dengan mengamati jalannya tindakanterhadap adanya pembelajaran dengan strategi Discovery learning. Pada tahap pelaksanaan (1) Guru melaksanakan pembelajaran dengan melakukan perbaikan proses dan informasi; (2) Guru mengefektifkan kelompok yang sudah ada; (3) guru mengadakan monitoring dan memberikan motivasi atas jalannya kerja kelompok; (4) guru mengadakan evaluasi atas hasil dari pembelajaran.pada siklus ke II.

.Berdasarkan hasil observasi atau pengamatan dan evaluasi selama pelaksanaan pembelajaran dengan menggunakan metode Discovery learning pada siklus II dapat dianalisis sebagai berikut.

a) Ditinjau dari aktivitas siswa

Berdasarkan hasil observasi terhadap kegiatan dalam pembelajaran dengan menggunakan metode Discovery learning keadaan situasi siswa dalam presentase dengan individu yaitu, (a) Minat dan perhatian siswa dalam proses belajar diperoleh hasil 25 siswa atau 84,21\%; (b) Keaktifan siswa dalam bertanya diperoleh hasil 25 siswa atau 84,21\%; (c) Keaktifan siswa dalam menjawab diperoleh hasil 22 siswa atau 73,68\%; (d) Keaktifan siswa dalam mengeluarkan pendapat diperoleh hasil 26 siswa atau $89,47 \%$

b. Ditinjau dari perhatian siswa

Dalam pembelajaran dengan meggunakan metodeDiscovery learning Dapat dilihat : (1) Perhatian siswa terhadap materi yang disampaikan diperoleh hasil 28 siswa yang aktif atau 94,73\%; (2) Perhatian siswa terhadap tugas yang diberikan diperoleh hasil 33 siswa yang aktif atau 86,84\%; (3) Keaktifan siswa dalam diskusi kelompok diperoleh hasil 26 siswa yang aktif atau 86,84\%; (4) Kebranian siswa dalam membacakan hasil diskusi diperoleh hasil 26 siswa yang aktif atau 86,84\%; (5) Perhatian siswa untuk menuliskan jawaban diperoleh hasil 24 siswa aktif atau $81,87 \%$.

c. Ditinjau dari ketuntasan belajar

Berdasarkan data yang diperoleh dapat dikatakan bahwa pembelajaran dengan menggunakan metode Discovery learning pada siklus II dikatakan berhasil. Dibuktikan dengan keadaan siswa yang tuntas belajar apabila KKM yang ditentukan 65 adalah sebanyak 27 siswa atau $89,47 \%$.

\section{Refleksi}

Dari hasil observasi ditemukan kekurangan dan kelemahan sebagai berikut :

a. Peneliti sudah bisa berdaptasi dengan siswa, sehingga dalam menyampaikan pembelajaran lebih mudah,

b. Siswa lebih senang dalam proses pembelajaran dengan menggunakan metode Discovery learning

c. Waktu sudah bisa teratasi karena penyampaian materi sudah terpenuhi dengan maksimal.

\section{PEMBAHASAN}

Atas dasar siklus I dan siklus ke II tersebut apabila kita bandingkan akan diperoleh hasil :

\section{Kegiatan Belajar Mengajar}

Berdasarkan hasil observasi dan refleksi pada pembelajaran pada siklus I dan siklus ke II, apabila kita bandingkan kaitannya dengan (a) Siswa belajar yang menyenangkan; (b) Siswa yang berani mengeluarkan pendapatnya; dan (c) Siswa yang antusias mengikuti pembelajara

\section{Tingkat Keaktifan Siswa}


Tingkat keaktifan siswa dalam siklus ke I dan ke II, dapat dilihat dalam hal (a) siswa berani bertanya; (b) siswa mau menjawab pertanyaan teman; (c) siswa berani menanggapi pendapat teman

Minat dan perhatian siswa dalam proses belajarterjadi peningkatan dari $56,77 \%$ menjadi $84,21 \%$ terjadi peningkatan $27,44 \%$; Keaktifan siswa dalam bertanya dari $71,73 \%$ menjadi $84,21 \%$ terjadi peningkatan $12,48 \%$; Keaktifan siswa dalam menjawab dari 71,02 menjadi 73,68\% terjadi peningkatan 2,66\%; Keaktifan siswa dalam mengeluarkan pendapat dari $68,4 \%$ menjadi $89,47 \%$ terjadi peningkatan $21,07 \%$.

Perhatian siswa terhadap materi yang disampaikan dari $86,84 \%$ menjadi 94,73\% terjadi peningkatan 7,89\%; Perhatian siswa terhadap tugas yang diberikan dari $78,94 \%$ menjadi $89,47 \%$ terjadi peningkatan $10,57 \%$; Kebranian siswa dalam membacakan hasil diskusi dari $84,27 \%$ menjadi $86,84 \%$ terjadi peningkatan $2,57 \%$; Kebranian siswa dalam membacakan hasil diskusi dari $81,57 \%$ menjadi $86,84 \%$ terjadi peningkatan 5,27\%; Perhatian siswa untuk menuliskan jawaban dari $78,94 \%$ menjadi $81,57 \%$ terjadi peningkatan $2,63 \%$.

Dengan demikian dapat diartikan bahwa menggunakan modelDiscovery Learning metode Inquiry dapat meningkatkan prestasi belajar siswa mata pelajaran ekonomi.

Apabila KKM ditentukan 65 dapat diketahui siswa yang tuntas belajar pada siklus I sebanyak 21 siswa dengan prosentase 68,4\% dan pada siklus II sebanyak 27 siswa dengan prosentase $89,47 \%$ sehingga dari siklus I ke siklus II naik $21,07 \%$. Siswa yang tidak tuntas belajar pada siklus I sebanyak 12 siswa dengan prosentase $31,6 \%$ dan pada siklus II sebanyak 4 siswa dengan prosentase 10,52\% sehingga dari siklus I dan II turun $21,08 \%$.

\section{Penutup Simpulan}

Berdasarkan hasil penelitian yang telah dipaparkan selama dua siklus, hasil seluruh pembahasan serta analisis yang telah dilakukan dapat disimpulkan sebagai berikut:

1. Pembelajaran kooperatif dengan modelDiscovery Learning metode Inquiry dapat meningkatkan kualitas pembelajaran .

2. Pembelajaran kooperatif dengan modelDiscovery Learning metode Inquiry memiliki dampak positif dalam meningkatkan prestasi belajar siswa ditandai dengan peningkatan ketuntasan belajar siswa dalam setiap siklus, yaitu siklus I $(68,4 \%)$, dan siklus II $(89,47 \%)$.

3. Pembelajaran kooperatif dengan modelDiscovery Learning metode Inquiry, siswa dapat bekerja secara mandiri maupun kelompok, serta mampumempertangungjawabkan segala tugas individu maupun kelompok.

4. Penerapan model pengajaram modelDiscovery Learning metode Inquiry dalam pembelajaran kooperatif mempunyai pengaruh positif, yaitu dapat meningkatkan motivasi, minat perhatian serta partisipasi belajar siswa.

\section{Saran}

Berdasarkan kesimpulan hasil penelitian di atas, penerapan pembelajaran kooperatif dengan modelDiscovery Learning metode Inquiry dapat meningkatkan keaktifan siswa dan hasil belajar. Untuk itu ada beberapa saran yang perlu disampaikan peneliti diantaranya:

Bagi guru

a. Hendaknya guru sering menggunakan metode-metode pembelajaran lain baik dengan 
menggunakan model Discovery Learning metode Inquiry dalam mencapai tujuan pembelajaran.

b. Dalam penerapan teknik pembelajaran dengan diskusi kelompok diharapkan guru memiliki kesiapan yang lebih matang, mampu membimbing dan memotivasi siswa agar setiap anggota kelompok berpartisipasi secara aktif dalam kegiatan pembelajaran.

Bagi kepala sekolah

Hendaknya kepala sekolah menyediakan sarana prasarana yang lengkap yang dapat menunjang proses belajar mengajar. Serta terus menggunakan metode-metode baru yang membangkitkan semangat siswa dalam belajar agar tidak cepat bosan.

\section{DAFTAR PUSTAKA}

Endang Ekowati, 2005. Pendekatan Pembelajaran Kontektual, Depertemen Pendidikan Nasional Direktorat Jendaral Pendidikan Dasar dan Menegah. Pusat Pengembangan Penataran Guru IPS dan PMP Malang.

Mel Siberman, 2005, Active Learning : 101 Strategi Pembelajaran Aktif, Diterjemahkan oleh Sarjuli, dkk., Yogyakarta: Yapendis.

H. Dakir. 2004. Perencanaan dan Pengembangan Kurikulum.Jakarta: Rineka Cipta.

Ngalim Purwanto.2002. Psikologi Pendidikan.Bandung: Remaja Rosdakarya.

Nurhadi. 2005. Kurikulum 2004 Pertanyaan dan Jawaban. Jakarta: Gramedia Widiasarana. Indonesia

Oemar Hamalik.2003. Pendidikan Guru Berdasarkan Pendekatan Kompetensi.Jakarta: Bumi Aksara.

Peraturan Menteri Pendidikan dan Kebudayaan Republik Indonesia Nomor 65 Tahun 2013tentang Standar Proses Pendidikan Dasar dan Menengah

Peraturan Menteri Pendidikan dan Kebudayaan Republik Indonesia Nomor 68 Tahun 2013 tentang Kerangka Dasar dan Struktur Kurikulum SMA/MA

Peraturan Menteri Pendidikan dan Kebudayaan Republik Indonesia Nomor 81a Tahun 2013 tentang Implementasi Kurikulum

Pupuh Fathurrohman, dkk. 2007. Strategi Belajar Mengajar. Bandung: Aditama.

Roestiyah.NK. 2001. Strategi Belajar Mengajar. Jakarta: Rineka Cipta.

Silberman, Mel. 2005. Active Learning: 101 Strategi Pembelajaran Aktif. Terjemahan oleh Sarjuli dkk. Yogyakarta: Yayasan Pengkajian dan PengembanganIlmu-ilmu Pendidikan Islam.

Suharjono.2006. Penelitian Tindakan Kelas.Jakarta: Bumi Aksara.

Suharsimi Arikunto Dkk.2006. Penelitian Tindakan Kelas.Jakarta: Bumi Aksara. 
Syaiful Bahri Djamarah dan Aswan Zain. 2002. Strategi Belajar Mengajar. Jakarta: Rineka Cipta.

Syaiful Bahri Djamarah. 2002. Psikologi Bel ajar.Jakarta: Rineka Cipta. 